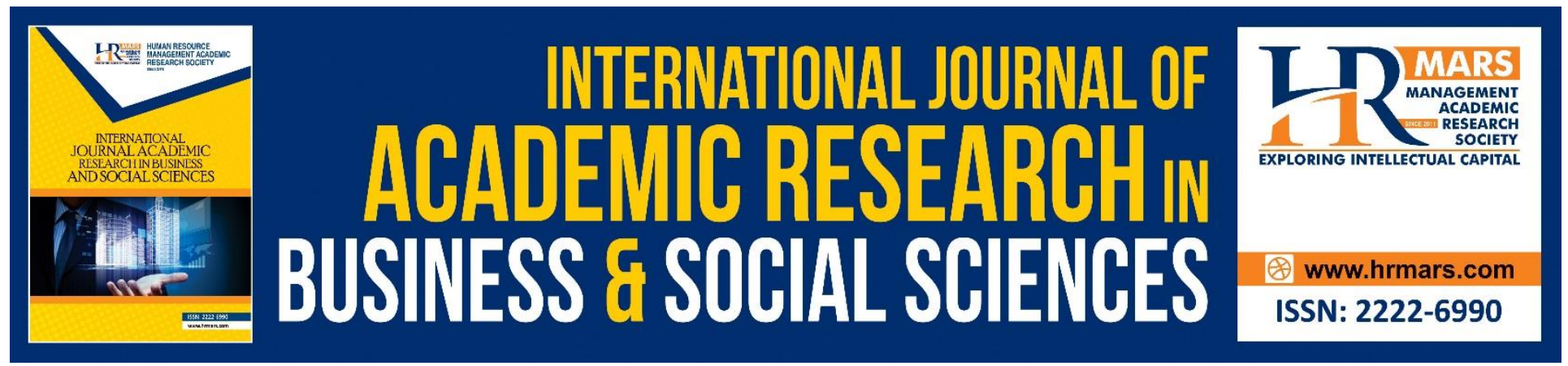

\title{
1AZAM Programme: The Challenges and Prospects of Poverty Eradication in Malaysia
}

\section{Radieah Mohd Nor, Hamoon Khelghat-Doost}

To Link this Article: http://dx.doi.org/10.6007/IJARBSS/v9-i1/5420

DOI: $\quad 10.6007 /$ IJARBSS/v9-i1/5420

Received: 23 Dec 2018, Revised: 29 Jan 2019, Accepted: 30 Jan 2019

Published Online: 07 Feb 2019

In-Text Citation: (Nor \& Khelghat-Doost, 2019)

To Cite this Article: Nor, R. M., \& Khelghat-Doost, H. (2019). 1AZAM Programme: The Challenges and Prospects of Poverty Eradication in Malaysia. International Journal of Academic Research in Business and Social Sciences, 9(1), 345-356.

\section{Copyright: (c) 2019 The Author(s)}

Published by Human Resource Management Academic Research Society (www.hrmars.com)

This article is published under the Creative Commons Attribution (CC BY 4.0) license. Anyone may reproduce, distribute, translate and create derivative works of this article (for both commercial and non-commercial purposes), subject to full attribution to the original publication and authors. The full terms of this license may be seen

at: http://creativecommons.org/licences/by/4.0/legalcode

Vol. 9, No. 1, 2019, Pg. 345 - 356

http://hrmars.com/index.php/pages/detail/IJARBSS

JOURNAL HOMEPAGE

Full Terms \& Conditions of access and use can be found at http://hrmars.com/index.php/pages/detail/publication-ethics 


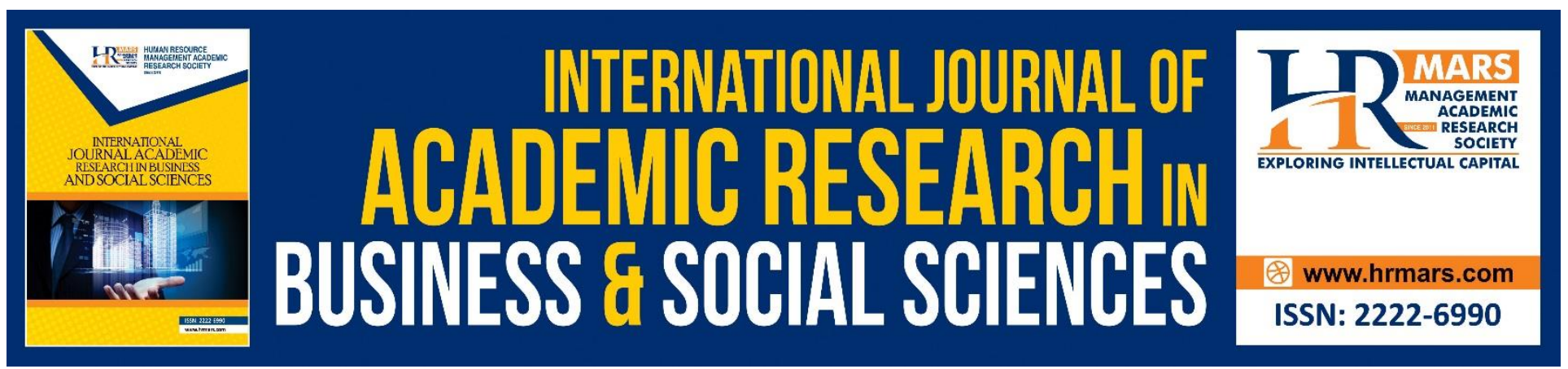

\title{
1AZAM Programme: The Challenges and Prospects of Poverty Eradication in Malaysia
}

\author{
Radieah Mohd Nor, Ph.D \\ Centre for Global Sustainability Studies, Universiti Sains Malaysia, Penang, Malaysia \\ Hamoon Khelghat-Doost, Ph.D \\ Centre for Global Sustainability Studies, Universiti Sains Malaysia, Penang, Malaysia
}

\begin{abstract}
This article aims to look at the challenges and constraints faced by the government to eradicate poverty through the 1AZAM programme. 1AZAM is a major programme introduced by the Malaysian government beginning in 2010 to help the poor to increase their income and break out of poverty. This qualitative research employs unstructured interviews which involves using random sampling from 53 participants to examine the level of participant's earnings before and after participating in the programme. In addition, in-depth interviews are also conducted with two government implementing agencies managing the 1AZAM programme to identify the constraints and challenges faced by these agencies in implementing the programme. The data that has been analysed using textual analysis find that participants income level increases after participating in the programme. However, there are challenges and constraints faced by the participants in their effort to increase their income. The challenges and constraints encountered in the programme can be divided into four. Firstly, the Key Performance Indicator (KPI) does not meet the Poverty Line Income set by the country. Secondly, a waste of government allocation in the programme. Thirdly, eKasih, the national poverty database needs to be fine-tuned. Finally, the incomprehensive monitoring method for 1AZAM participants. The 1AZAM programme is found to be very helpful to participants to increase their income. However, these four points should be considered by the implementing agencies so as to maximize the impact on those target groups.
\end{abstract}

Keywords: Poverty Eradication; AZAM Programme; Ekasih System

\section{Introduction}

Malaysia is located in Southeast Asia with a population of 31.6 million people in 2016 and with estimated growth to 32.0 million people in 2017 (Department of Statistics Malaysia, 2017). In 2016, Malaysia's Gross National Product (GNP) income was RM1,107.9 billion and its per capita income is MYR7,738 (Bank Negara, 2016). Malaysia is trying to improve its position in the eyes of the world as 
the country pushes forward in becoming a developed nation by the year 2020 (EPU, 2017a). This has led Malaysia to formulate its development policy in the $11^{\text {th }}$ Malaysian Plan 2016-2020 by stipulating that inclusive development will be made available to all Malaysians in the pursuit of Malaysia achieving high-income developed nation status (EPU 2017b).

Among the government's aspirations in achieving inclusive development is to increase the Bottom $40 \%$ (B40) households with income of RM3,860 and below to the Middle 40\% (M40) whose range of income is between $\mathrm{RM} 3,855$ to $\mathrm{RM} 8,319$. Its main purpose is to address the rising cost of living which is affecting the B40 group (Fairul, personal communication, January 25, 2017).

The government has carried out poverty eradication programmes to address the issue of higher living cost. This includes the 1AZAM programme which is the mainstay for other poverty eradication programmes. The 1AZAM programme was originally an Income Generation Programme. The word AZAM itself is an acronym for 'Akhiri Zaman Miskin' (Break the Cycle of Poverty). Participants are selected through the eKasih Database system which is a national poverty database created to aid in planning, implementing and monitoring of poverty programmes (PMR, 2018).

The 1AZAM programme has indirectly helped to free this group from the shackles of poverty through their own efforts. The Ministry of Women, Family and Community Development (KPWKM) is the ministry responsible for leading the programme. Other ministries and agencies which are also involved are the Ministry of Agriculture and Agro-Based Industry (KPIT), Ministry of Human Resources $(\mathrm{MOH})$, Ministry of Agriculture and Family Development Sarawak (KKWPK), Ministry of Housing and Local Government (KPKT) and Amanah Ikhtiar Malaysia (AIM).

There are five main programmes conducted under the 1AZAM programme namely AZAM Kerja (Aim Works), AZAM Tani (Aim Agricultural), AZAM Niaga (Aim Business), Azam Bandar (Aim City) and AZAM Khidmat (Aims Services) (Nor and Azhar, 2016). However, there are also 1AZAM Sabah and 1AZAM Sarawak which are self-administered by the respective state governments.

The programme which was introduced in 2010 and fully implemented in 2011 was aimed at creating an economic opportunity to increase productivity of the low-income households. This programme applied the entrepreneurship concept aimed at maximizing individual potential based on the individual's skills or interests (Mohd, 2013). For example, the Ministry of Agriculture and Agrobased Industry (KPIAT) provides AZAM Tani with agricultural equipment, livestocks and agricultural inputs. The KPIAT also provides advisory service, coaching and training to the participants.

Through Azam Niaga, the KPWKM offers 21 packages to selected participants. Implementing agency for KPWKM is the National Welfare Foundation/ Yayasan Kebajikan Negara (YKM). Through this programme, participants will be supplied goods according to their needs and interests as illustrated in Table 3. 
INTERNATIONAL JOURNAL OF ACADEMIC RESEARCH IN BUSINESS AND SOCIAL SCIENCES

Vol. 9, No. 1, Jan, 2019, E-ISSN: 2222-6990 @ 2019 HRMARS

Table 3 Agriculture and agro-based industries projects under the AZAM Tani programme

\begin{tabular}{ll}
\hline SECTOR & TYPE OF PROJECTS \\
\hline Crops & $\begin{array}{l}\text { Short-term crops - corn, watermelon, mushrooms and } \\
\text { chilli fertigation } \\
\text { Ikan patin, ornamental fish, fishing equipment, caged fish } \\
\text { farming, freshwater fish farming and prawn farming }\end{array}$ \\
\hline Farming & Swiftlet, honey bees, ducks and chickens \\
\hline Food processing & $\begin{array}{l}\text { Cakes, dried fish, crackers, salted fish, traditional snacks, } \\
\text { frozen foods, sauces, chips, drinks and juices, salted eggs, } \\
\text { coconut milk, kerisik (grated, toasted and pounded coconut } \\
\text { paste) and coconut jelly } \\
\text { Product-based business }\end{array}$ \\
Sugarcane juice, soy-based products, cut fruits, banana \\
fritters, crackers, nasi lemak, roti canai, kebabs and sales of \\
fresh fish
\end{tabular}

Source: Nor and Azhar (2016)

The 1AZAM programme is not designed to make them rich participants but it is introduced to help the poor to increase their monthly income by at least RM300 from their existing income. In fact, the RM300 increment is not enough to remove them from the national Poverty Line Income (PGK) set at RM950 (Fairul, personal communication, January 25, 2017). The programme is introduced by the federal government to help the poor to break out of poverty through their own efforts and be able to achieve viability. The slight increase in earnings of RM300 compared to the previous income can be considered as a good initial step with the hope that they will be out of poverty someday.

It was hoped that with the training and coaching received in the programme, the participants will not only gradually break their cycle of poverty but have a competitive mindset as well. The Ministry of Women, Family and Community Development (KPWKM) identified that there were participants who were able to progress well in the programme. These successful participants were further empowered with additional aid from a programme known as 'Beyond 1Azam' (New Straits Times, 2014). They will be given more skills to expand their business so they can compete not only in countries but also market their products out of the country.

In their effort to further strengthen poverty management in Malaysia, the government introduced eKasih which is the National Poverty Data Bank. The eKasih system is a poor family database created at the national level to help plan, implement and monitor the poverty programmes implemented by the agencies involved. The eKasih was created following a decision reached at the Cabinet Meeting on 31 October 2007 and the State Chief Ministers' Meeting on 1 November 2007. As a result, the system was developed in-house by the Implementation Coordination Unit (ICU JPM) and was first used in June 2008 (PPPN Perak, 2015). 
INTERNATIONAL JOURNAL OF ACADEMIC RESEARCH IN BUSINESS AND SOCIAL SCIENCES

Vol. 9, No. 1, Jan, 2019, E-ISSN: 2222-6990 (C) 2019 HRMARS

However, there have been many issues involving the programme since its inception in 2010 . The Report of Public Accounts Committee of the Thirteenth Parliament from their survey presented on 24 March 2015 raised seven issues. The issues are as follows:

1. Selection of participants is not through eKasih database.

Based on a census conducted by the National Audit Department, the status of $58 \%$ or 58 participants was unknown. As many as eight participants were not registered in the eKasih database. This means the selection system was not entirely done through eKasih although it was stipulated that the selection of participants must be done through the database.

2. No Standard Operating Procedure (SOP) for selection of goods supplier.

The hiring of 22 suppliers of goods for the 1AZAM programme involved an allocation of RM 8 million. However, the selection process cannot be justified as no standard operating procedure (SOP) was provided for the purpose of supplier selection.

3. Participants did not use the equipment supplied to them.

64 participants out of 265 participants did not utilize the equipment supplied which eventually led to wastage.

\section{Missing participants.}

The National Audit Department of Malaysia also conducted a study on 370 participants by visiting their homes. The visit was to observe their progress after obtaining the intended assistance. However, out of the 370 participants, 33 participants' whereabouts were unknown.

\section{The delay in opening 1 AZAM bank account}

The National Welfare Foundation (YKN), the implementer of 1AZAM under the KPWKM only opened a special 1AZAM account on 19 September 2014 by depositing a total of RM5.51 million from the RM165.51 million allocation of 1AZAM into a current account at Alliance Islamic Bank. The rest was kept in fixed deposit accounts at 10 local banks. The delay in opening this account should not have occurred as the programme was launched in 2010.

\section{Group projects have yet to generate revenue.}

Three of the five sample projects carried out under the Ministry of Agriculture and Agro-based Industry have yet to generate revenue. These group projects involved 278 participants.

\section{Management of Goods to the Participants.}

The National Audit Department conducted a survey by selecting four suppliers from the 19 suppliers of goods to 1AZAM participants. The audit team studied the relevant documents and discovered there were many questionable transactions in the supply of the goods. These can be divided in two aspects; 
7.1 No detailed price of goods was received by the participants.

Based on the 1AZAM programme, each qualified participant is allocated RM5,000 in the form of equipment. However, KPWKM and YKN did not provide detailed pricing for the equipment components in each package received by the participants. This resulted in 22 suppliers submitting 23 quotations worth RM8 million without including the price for each component of equipment included in one package. The offer prices submitted was based on a lump sum price of one package.

7.2. Scope of service provider.

The National Audit Department also found no evidence of warranty coverage for the equipment supplied by the suppliers to the participants. Apart from that, eight out of 10 participants reported that the equipment received was not durable, damaged and so on. Additionally, two participants who received equipment in the form of a cake oven were unable to use the equipment because their household voltage cannot accommodate the oven's power requirement.

Therefore, this study examines the challenges faced by the management and participants of 1AZAM in eradicating poverty especially in Penang as the state was not included in the 2016 audit report presented by the National Audit Department on the 1AZAM programme. The study aims to examine the latest development of the 1AZAM Programme two years after the audit report was released.

\section{Literature Review}

Not many studies were carried out by researchers on the 1AZAM Programme. To date, there are only three studies conducted by Mohd (2013), Nor and Azhar (2016) and Norhidayati and Radieah (2017). Mohd (2013) and Nor and Azhar (2016) focus more on the implementation and success of the programme in addressing poverty in Malaysia. Nevertheless, Norhidayati and Radieah (2017) further elaborate on the challenges faced by 1AZAM programme participants in improving their standard of living. In addition, Norhidayati and Radieah (2017) also found that the weaknesses in the eKasih data management system have huge implications on the management of the 1AZAM Programme. Based on their studies, there was data duplication in the eKasih system, the participants were not aware of their names being included in the eKasih system and participants whom have not received any assistance despite being eligible for the assistance.

This study is a continuation of previous studies conducted by Norhidayati and Radieah (2017). However, this study only focuses on 53 participants out of 100 1AZAM participants who were involved in the previous studies. In depth interviewing is carried out to find out the participants' condition before and after they joined the 1AZAM programme.

\section{Methodology}

This study carried out in-depth interview with the Principal Assistant Director of Distribution Section, Economic Planning Unit of Prime Minister's Department in January 2017. In addition, an in-depth interview was also conducted with the Principal Assistant Senior Director of the People's Wellbeing Division, Implementation Coordination Unit of Prime Minister's Department in October 2015. These two government agencies were interviewed as they are among the agencies responsible for 
INTERNATIONAL JOURNAL OF ACADEMIC RESEARCH IN BUSINESS AND SOCIAL SCIENCES Vol. 9, No. 1, Jan, 2019, E-ISSN: 2222-6990 (C) 2019 HRMARS

conducting the programme. The open-ended interviews were then analysed using textual analysis to understand the implicit reasons behind every problem and the implications that arise in the implementation of the 1AZAM programme. In-depth interviews were also conducted with 1AZAM participants $(N=53)$. Participants were selected from the state of Penang as the scope of investigation by the Auditor-General did not involve participants of this state. Random sampling methods wereused for in-depth interviews. The profile of 53 participants interviewed were as follows;

Table 1: The profile of the 1AZAM programme participants involved in the research interview

\begin{tabular}{lll}
\hline PROFILE & & TOTAL \\
\hline Gender & Male & 12 \\
Age & Female & 41 \\
& $20-30$ years & 10 \\
& $31-40$ years & 16 \\
& $41-50$ years & 17 \\
& $51-55$ years & 7 \\
Level of & $56-59$ years & 3 \\
Education & Never attended & 4 \\
& school & \\
& Primary school & 6 \\
& Lower Secondary & 14 \\
& Upper Secondary & 21 \\
\multicolumn{2}{l}{ Total number of participants } & 8 \\
\hline
\end{tabular}

\section{Research Findings and Discussion}

Based on the problem statement previously discussed, most of the problems arise from the unsystematic system management which eventually affected the success of the programme. Even though such a situation occurred in the 1AZAM programme, there were also participants who were able to get out of the cocoon of poverty through this programme. This was due to their hard work and diligence in fully utilizing the 1AZAM programme which in return have positively impacted their lives (Auditor-General, 2016).

The study focuses on the challenges and obstacles faced by the implementing agencies. 53 out of 3,176 participants throughout Penang who were listed in the eKasih database were interviewed. In addition, two implementing agencies were also interviewed for further clarification on the issues raised either by the participants or the National Audit Department. The findings show that there are four elements that posed as challenges and constraints for the 1AZAM Programme. The four elements are as discussed in the next sub topic.

The Key Performance Indicator was set lower than the Poverty Line Income Based on AZAM Niaga's programme, 93,469 participants out of 195,953 participants (recorded until October 2016) have succeeded in raising their earnings (Azizah, 2016, November 2). This means that 
INTERNATIONAL JOURNAL OF ACADEMIC RESEARCH IN BUSINESS AND SOCIAL SCIENCES Vol. 9, No. 1, Jan, 2019, E-ISSN: 2222-6990 (C) 2019 HRMARS

only $47.7 \%$ of participants have managed to increase their income. More worryingly, when the Key Performance Indicator (KPI) used to determine the success of the programme is an increase of RM300 for any three months (PEMANDU, 2015: 76). The above mentioned KPI is in fact contrary to the Poverty Line Income (PGK) with the value set by Malaysia is at RM950 (Fairul, personal communication, January 25, 2017).

The conflicting KPI set out in the 1AZAM programme with PGK set by the country have a major implication on poverty statistics in Malaysia. Although there were participants who have successfully participated in the programme, they did not necessarily surpass the PGK. Indirectly, participants who have not surpassed PGK are still in poverty. This means that even if the statistics of the successful participants are recorded through the programme, it may not necessarily represent the statistical success of PGK Malaysia.

\section{Wasting funds allocated for the programme}

Mismanagement of funds which occurred at the low level has made this programme unsuccessful. The allocation of substantial fund by the government to ensure the success of the programme was misspent. As noted in the report from the National Audit Department (2016), RM1.45 billion allocation was allocated for the period of 2011 to 2013. In addition, each participant received a grant of RM5,000 to RM10,000 either in the form of equipment or soft skills to generate their economy.

However, such provisions did not benefit the participants as equipment such as refrigerators, sewing machines and ice-cream machines were damaged and non-durable (Auditor-General, 2016). Additionally, based on interviews with 66 participants who sought the aid, 53 participants have received the assistance. However, 14 other participants still have not received any help.

The same findings are gathered during this study. For example, the assistance given to Persons with Disabilities (OKU) did not match the participants' physical condition. Based on the interviews conducted, there were blind recipients who were given cake-making equipment such as oven, flour machine and others when they were unable to fully utilize the equipment due to their disability. There were other participants who complained about receiving damaged oven and tried to repair it but was not successful. Even though complaints about the damages were made, no action was taken. Similarly, a participant who received a carpentry tool in a form of a damaged grinder machine. Although he lodged a complaint about the damaged goods, no action was taken either.

Apart from that, one participant also informed that he received two sewing machines - one for straight stitching and another for edge stitching to help him with his tailoring business. However, the edge stitching sewing machine cannot be used due to its poor quality and was more suitable for sewing lessons. Thus, he had to incur extra cost every time he sent his sewing work to another tailor for edge stitching sewing because he did not have a good edge stitching sewing machine.

One surprising finding discovered during this study was one of the recipients received an ASTRO Njoi. Such equipment cannot help him to increase his income as it is a free satellite television service in Malaysia. According to the beneficiary, he made a request for a boat engine so as to able him to fish in the sea but the aid was never received.

Based on these findings, it is apparent that the equipment received by the participants were of poor quality, no product warranty against damages was given to the participants and also many equipment were not relevant to the participants' needs. This has disrupted their efforts to increase 
INTERNATIONAL JOURNAL OF ACADEMIC RESEARCH IN BUSINESS AND SOCIAL SCIENCES

Vol. 9, No. 1, Jan, 2019, E-ISSN: 2222-6990 (C) 2019 HRMARS

their income. The findings also pointed out that there was still no action taken by the goods suppliers regarding the absence of product warranty despite the Auditor-General's report (2016) was released two years ago.

\section{The eKasih registry for the poor needs to be fine-tuned}

The National Poverty Data Bank or better known as eKasih is a system that stores data of the poor in Malaysia (ICU, 2016). Based on the study that was carried out, the eKasih system, a registry for the poor in Malaysia needs to be upgraded because there are many poor people who are still not registered under eKasih. Indirectly, the eKasih system does not reflect the actual population of the poor in Malaysia.

Currently, the registered individuals in the system are based on the initiative taken by the village committee members and local authorities such as state assemblymen (ADUN) and others. If the village committee members, ADUN and others do not take similar initiative, the registration of the poor in the eKasih system will be affected. Collaboration needs to be done by the community to assist the poor in the community to assist the poor who are not informed about the assistance provided by the government.

The eKasih system should be updated automatically without registration by any party because the government under the Inland Revenue Board (IRB) has the household database that stores individual income information. In addition to tax collection, the IRB is also entrusted in giving out aid money known as 1Malaysia People's Aid or BR1M. Through tax collection and BR1M, the government is actually capable of identifying poor households or individuals in Malaysia. However, according to Izamalina (2015), not all poor Malaysians agreed to be registered in the system. Therefore, the individuals listed in the system are those who have agreed to their names being registered. They disagree for a variety of reasons. Among them is because of shame, do not want to be helped, consider it not important and some also consider them not in the category of the poor.

However, based on this research interviews, it is surprising to find out that there were participants who did not know how their names were registered in the e-Kasih. Based on the interview, ten participants did not know about the 1AZAM programme and that their names were registered in the programme without their knowledge. Based on this feedback, they also did not know about the existence of the eKasih system.

In order to gain certainty about the eKasih system, an interview was conducted at the People's Wellbeing Division, Implementation Coordination Unit of Prime Minister's Department. The interview with the Principal Assistant Senior Director found that the eKasih system was still under process improvement. In future, the eKasih system will be linked to all the agencies involved such as the tithe management centres, Department of Social Welfare, AIM and other agencies to centralize related information. This can also avoid duplication of assistance to the poor households so much so that some may receive too much aid while other poor households are denied their rights.

\section{The monitoring method for 1Azam programme participants needs to be comprehensive}

Based on the interviews conducted with selected participants through random sampling throughout Penang, it was found that the monitoring of 1AZAM participants by the authorities was not comprehensive. There were participants who stated that no one kept track of their progress 
throughout their participation in the programme. On the other hand, according to the information received from the 1AZAM executives, interviews will be carried out with the participants as well as physical visits to validate the progress of each participant. When this situation was brought forward to the attention of Distribution Section, the Economic Planning Unit of the Prime Minister's Department, they acknowledged that they were aware of the constraints. According to them, this situation happened because there was not enough manpower to monitor 1AZAM participants. This has caused an attrition in the monitoring process. Improvements are being made so that these problems can be fixed and the programme becomes a platform in eradicating poverty. This platform has also helped single mothers who participated in the programme. Based on the interviews conducted, there were 17 single mothers. Indirectly, this programme has helped them to increase their income.

\section{Conclusions}

A study on participants of 53 different 1AZAM programmes were conducted to evaluate the difference before and after participating in the program. Interviews were also conducted on two government agencies managing the 1AZAM programme. In the context of textual analysis, study found that income level increases after participating the programme. However the findings shows that the Poverty Line Income set by the country does not meet the Key Performance Indicator (KPI) in this programme. The KPI is shown to be lower than the Poverty Line Income. The study also found some participants failed to fully utilize the equipment that were given to them and eKasih as the national poverty database system needs to update the overlapping and incomplete data in the system. These problems have affected the level of assistance to be provided to the poor to a mere average level.

Based on the research findings, researchers suggested that the government should improve the 1AZAM program with the KPI of the program necessarily in tandem with the Poverty Line. Additionally, studies of individuals applying to receive assistance should also be conducted carefully. Thus, monitoring of beneficiaries also needs to be done periodically. The eKasih system and data obtained should also to be constantly updated so that all agencies are responsible for assisting the poor in Malaysia.

Based on the planning that has been done, the programme had proven to have a huge potential in helping the poor from poverty and become a viable society. Therefore, the good add-ons of the programme should be implemented as soon as possible as the time frame towards Malaysia becoming a high-income developed nation by 2020 is running short.

\section{ACKNOWLEDGEMENT}

This paper is a part of a research funded by Research University Grant (1001/PCGSS/816308) awarded by Universiti Sains Malaysia. The writers wish to express their heartiest gratitude to all other parties who have been involved either directly or indirectly in this research.

\section{REFERENCES}

Azizah, M. (2016, November 2) Parliament Malaysia Official Statement, Parliament Hansard, Dewan Rakyat, The Thirteenth Parliament. Malaysia: Parliament Malaysia Official. 
INTERNATIONAL JOURNAL OF ACADEMIC RESEARCH IN BUSINESS AND SOCIAL SCIENCES

Vol. 9, No. 1, Jan, 2019, E-ISSN: 2222-6990 ㄷ 2019 HRMARS

Central Bank of Malaysia (2016) Perkembangan Ekonomi Pada Tahun 2016. Retrieved from www.bnm.gov.my/files/publication/ar/bm/2016/cp01.pdf

EPU, Economic Planning Unit (2015) The Eleventh Malaysia Plan. Putrajaya: The Prime Minister's Department of Malaysia.

EPU, Economic Planning Unit (2017a) Vision 2020. Retrieved from http://www.epu.gov.my/en/development-policies/vision-2020

EPU, Economic Planning Unit (2017b) Eleventh Malaysia Plan. Retrieved from http://www.epu.gov.my/en/rmk/eleventh-malaysia-plan-2016-2020

Fairul, F. A. (2017, January 25) Personal Interview.

ICU, Implementation Coordination Unit (2016) Info eKasih. Retrieved from https://ekasih.icu.gov.my/Pages/InfoeKasih.aspx

Izamalina, Y. (2015, September 1) Personal Interview.

Department of Statistics Malaysia (2017) Siaran Akhbar Anggaran Penduduk Semasa, Malaysia, 20162017. Retrieved from https://www.dosm.gov.my/ v1/index.php?r=column/pdf Prev\&amp;id=VUdaQ2tVVjcwTEFUVWp5aTVQbjV1UT09

National Audit Department (2016) Laporan Jawatankuasa Kira-kira Wang Negara (PAC) Parlimen Berhubung Pengurusan Program 1AZAM oleh Kementerian Pembangunan Wanita, Keluarga dan Masyarakat. Kuala Lumpur: Dewan Rakyat Ketiga Belas Penggal Keempat.

Mohd, A. A. R. (2013) Kejayaan Malaysia dalam Program Basmi Kemiskinan. Putrajaya: Department of Information, Malaysia.

Norhidayati, N. and Radieah, M. N. (2016) "1AZAM Program Implementation In Penang, Malaysia:Towards Poverty Eradication". The papers presented in International Conference on Sustainable Development Goals (ICSDG2016). Organized by South East Asia Sustainability Network (SEASN) on 7-8 Disember 2016 at Universiti Sains Malaysia.

New Straits Times (2014, Jun 17) Beyond 1AZAM Programme for Successful 1AZAM Participants. Retrieved from http://www.nst.com.my/news/2015/09/beyond-1azam-programmesuccessful-1azam-participants

Nor, R. and Azhar, S. (2016) 1AZAM Aiding Low-Income Households in Malaysia. Journal of Human Resource and Sustainability Studies, 4, 293-304. DOI: 10.4236/jhrss.2016.44029. 
INTERNATIONAL JOURNAL OF ACADEMIC RESEARCH IN BUSINESS AND SOCIAL SCIENCES

Vol. 9, No. 1, Jan, 2019, E-ISSN: 2222-6990 C 2019 HRMARS

PEMANDU, Performance Management and Implementation Unit (2015) GTP: Program Transformasi Kerajaan: Laporan Tahunan 2014. Putrajaya: Performance Management and Implementation Unit.

PPPN Perak, Federal Development Office of Perak (2015) FAQ Permohonan Bantuan E-Kasih. Retrieved from http://www.prk.icu.gov.my/v3/index.php/layout1/252

UNDP, United Nation Development Programme (2016) Human Development Index and Its Components. Retrieved from http://hdr.undp.org/en/composite/HDI

World Bank (2017) GDP per capita (current US\$). Retrieved from http://data.worldbank.org/indicator/NY.GDP.PCAP.CD

World Bank (2014) Reducing Extreme Poverty in Indonesia. Retrieved from http://www.worldbank.org/en/country/indonesia/brief/reducing-extreme-poverty-inindonesia

PMR, Portal Pusat Maklumat Rakyat (2018) Sistem e-Kasih. Retrieved from http://pmr.penerangan.gov.my/index.php/nkra/11474-sistem-ekasih.html

Joshee, R. (2009) "Grameen Model: Problems and Prospects" The papers presented in the Microfinance Summit, Februari 14-16, 2008, Kathmandu, Nepal. Accessed from https://www.microfinancegateway.org/library/grameen-model-problems-and-prospects

AIM, Amanah Ikhtiar Malaysia (2018) Tentang Amanah Ikhtiar Malaysia. Retrieved from http://aim.gov.my/

KPWKM, Ministry of Women, Family and Community Development, Malaysia (2016) Bidang Keberhasilan Utama Negara (NKRA) Mempertingkatkan Taraf Kehidupan Isi Rumah $\begin{array}{llll}\text { Berpendapatan } & \text { Rendah } & \text { (LIH). } & \text { Retrieved from }\end{array}$ https://www.kpwkm.gov.my/kpwkm/uploads/files/NKRA/SOALAN\%20LAZIM\%20PROGRAM \%201AZAM.pdf 